\title{
A prospective clinical trial to evaluate the prevalence of thyroid disorder among pregnant women and obstetrical and fetal outcome in a tertiary health centre located in central India
}

\author{
Manjari G. Jain ${ }^{1 *}$, Neeraj K. Jain ${ }^{2}$, Mita Mazumdar ${ }^{1}$ \\ ${ }^{1}$ Department of Obstetrics and Gynecology, RKDF Medical College and Research Centre, Bhopal, Madhya Pradesh, \\ India \\ ${ }^{2}$ Department of Surgery, Atal Bihari Vajpayee Govt. Medical College, Vidisha, Madhya Pradesh, India
}

Received: 18 May 2020

Accepted: 29 June 2020

\section{*Correspondence:}

Dr. Manjari G. Jain,

E-mail: minigoel86@gmail.com

Copyright: ( ) the author(s), publisher and licensee Medip Academy. This is an open-access article distributed under the terms of the Creative Commons Attribution Non-Commercial License, which permits unrestricted non-commercial use, distribution, and reproduction in any medium, provided the original work is properly cited.

\section{ABSTRACT}

Background: A prospective clinical trial to evaluate the prevalence of thyroid disorder among pregnant women and obstetrical and fetal outcome was done in a tertiary health centre (RKDF Medical College and Research Centre, Bhopal) located in central India.

Methods: This prospective study was carried out in antenatal women in their first trimester attending antenatal OPD in RKDF Medical College and Research Centre, Bhopal, Madhya Pradesh to know the prevalence of thyroid disorder and its association with pregnancy outcome.

Results: In this study prevalence of thyroid disorder was $12.4 \%$, subclinical hypothyroidism $7.2 \%$, overt hypothyroidism $3.4 \%$, subclinical hyperthyroidism $1.4 \%$, overt hyperthyroidism $0.4 \%$. Thyroid disorder is responsible for several obstetrical and fetal complication like pre-eclampsia, preterm delivery, abortion, IUGR and low birth weight.

Conclusions: Thyroid disorder associated with poor obstetrical outcome and fetal complication. so timely diagnosis and treatment is required. Universal screening should be preferred over high-risk screening because of high prevalence of the disease in India.

Keywords: Hyperthyroidism, Overt hypothyroidism, Overt hyperthyroidism, Pregnant women, Subclinical hypothyroidism, Subclinical, Thyroid disorder

\section{INTRODUCTION}

Thyroid disorder is one of the commonest endocrine disorders in young women of reproductive age. ${ }^{1}$ Thyroid disorder in pregnancy associated with adverse outcome in mother and foetus. ${ }^{2}$

Pregnancy is associated with change in the physiology of pituitary thyroid axis, iodine metabolism and immune function. The total serum $\mathrm{t} 3$ and $\mathrm{t} 4$ level increase during pregnancy due to increase in thyroxin binding globulin. ${ }^{3}$ Increase in TBG, occurs due to increase synthesis, under the influence of oestrogen. Although, free hormone level remains unchanged. HCG shows structural similarity with TSH and cause transient increase in free thyroxin level, as a result TSH levels are suppressed.

Between $2.2 \%-2.5 \%$ of women have been found to have TSH level of $6 \mathrm{mIU} / \mathrm{L}$ or greater, at 15 to 18 weeks of gestation. ${ }^{4}$ In normal pregnant women, the thyroid gland maintains euthyroidism with minor fluctuation.

In women with limited thyroid reserve due to thyroid autoimmunity or iodine deficiency hypothyroidism can 
develop. ${ }^{5}$ While the American thyroid association not recommends, universal screening but expert suggest number of pregnant women with thyroid disorder would be missed, if only high-risk patients were examined, so more extensive screening is required.

The objective of this study was to evaluate the prevalence of thyroid disorder among pregnant women, and its obstetrical and fetal outcome.

\section{METHODS}

This study was done at RKDF Medical College and Research Centre, Bhopal in department of obstetrics and gynecology from $1^{\text {st }}$ December 2018 to $30^{\text {th }}$ November 2019.

The study approved by research ethics committee at hospital.

It is prospective study includes 1000 pregnant women in their first trimester and informed consent was obtained from all women.

\section{Inclusion criteria}

- First trimester of pregnancy, singleton pregnancy, primi/multigravida.

\section{Exclusion criteria}

- Multifetal gestation, history of hypertension, diabetes, previous bad obstetrics history with known cause.

After taking informed consent from subjects, detail history was taken, general examination, systemic examination, per abdominal and per vaginal examination was done. Pregnancy confirmed by urine pregnancy test and ultrasonography. Routine antenatal profile testing was done.

\section{Specific investigation}

All patient tested for serum TSH level, if serum TSH values were deranged than free $\mathrm{t} 3$ and free $\mathrm{t} 4$ levels were tested.

(As per regulation of American thyroid association guidelines)

In this study, following normal reference ranges are recommended

- $\quad$ First trimester 0.1 to $2.5 \mathrm{mIU} / \mathrm{L}$

- Second trimester 0.2-3 mIU/L

- Third trimester 0.3-3 mIU/L

- $\quad$ Normal free t4 level is 0.7-1.8 nanogram per ml

- Free t3 level is 1.7 to $4.2 \mathrm{pg} / \mathrm{ml}$.
Based on the hormone values, patients were classified into-

- Subclinical hypothyroidism: high serum TSH and normal $\mathrm{ft} 4$ and $\mathrm{ft} 3$

- Overt hypothyroidism: high serum TSH and $\mathrm{ft} 3$ and $\mathrm{ft} 4$ less than normal

- Subclinical hyperthyroidism: low serum TSH and normal $\mathrm{ft} 3$ and $\mathrm{ft} 4$

- Overt hyperthyroidism: low serum TSH and $\mathrm{ft} 3$ and $\mathrm{ft} 4$ more than normal.

Following obstetrical and fetal outcome of pregnancy in relation to thyroid disorder were studied. Abortion, abruptio placenta, preeclampsia, preterm delivery, IUGR, low birth weight and stillborn.

\section{RESULTS}

Table 1: Prevalence of types of thyroid disorder among 1000 pregnant women.

\begin{tabular}{|lll|}
\hline $\begin{array}{l}\text { Types of thyroid } \\
\text { disorder }\end{array}$ & $\begin{array}{l}\text { No. of cases in } \\
\mathbf{1 0 0 0} \text { patients }\end{array}$ & Percentage \\
\hline $\begin{array}{l}\text { Subclinical } \\
\text { hypothyroidism }\end{array}$ & 72 & $7.2 \%$ \\
\hline $\begin{array}{l}\text { Overt } \\
\text { hypothyroidism }\end{array}$ & 34 & $3.4 \%$ \\
\hline $\begin{array}{l}\text { Subclinical } \\
\text { hyperthyroidism }\end{array}$ & 14 & $1.4 \%$ \\
\hline $\begin{array}{l}\text { Overt } \\
\text { hyperthyroidism }\end{array}$ & 04 & $0.4 \%$ \\
\hline
\end{tabular}

In the present study 124 out of 1000 pregnant woman screened found to have thyroid disorder. The prevalence of thyroid disorder was $12.4 \%$. In the present study prevalence of subclinical hypothyroidism is $7.2 \%$, overt hypothyroidism is $3.4 \%$, Subclinical hyperthyroidism is $1.4 \%$ and overt hyperthyroidism is $0.4 \%$.

Table 2: Thyroid stimulating hormone level in study cases.

\begin{tabular}{|llll|}
\hline $\begin{array}{l}\text { Types of } \\
\text { thyroid } \\
\text { disorder }\end{array}$ & $\begin{array}{l}\text { No. of cases } \\
\text { in } \mathbf{1 0 0 0} \\
\text { patients }\end{array}$ & Mean & $\begin{array}{l}\text { Standard } \\
\text { deviation }\end{array}$ \\
\hline $\begin{array}{l}\text { Subclinical } \\
\text { hypothyroidism }\end{array}$ & 72 & 4.2 & 1.24 \\
\hline $\begin{array}{l}\text { Overt } \\
\text { hypothyroidism }\end{array}$ & 34 & 8.6 & 2.94 \\
\hline $\begin{array}{l}\text { Subclinical } \\
\text { hyperthyroidism }\end{array}$ & 14 & 0.020 & 0.014 \\
\hline $\begin{array}{l}\text { Overt } \\
\text { hyperthyroidism }\end{array}$ & 04 & 0.012 & 0.006 \\
\hline
\end{tabular}

The mean TSH level in the cases of subclinical hypothyroidism, overt hypothyroidism, subclinical hyperthyroidism, overt hyperthyroidism was 4.2, 8.6, 0.02 and 0.012 respectively. 
Table 3: Maternal and fetal complication among patient of subclinical hypothyroidism.

\begin{tabular}{|lll|}
\hline Complication & $\begin{array}{l}\text { No. of cases in } \\
\mathbf{1 0 0 0} \text { patients }\end{array}$ & Percentage \\
\hline Preeclampsia & 8 & $11.1 \%$ \\
\hline Preterm delivery & 6 & $8 \%$ \\
\hline Abortion & 4 & $5.5 \%$ \\
\hline Abruptio placentae & 2 & $2.7 \%$ \\
\hline IUGR & 5 & $6.9 \%$ \\
\hline Low birth weight & 4 & $5.5 \%$ \\
\hline Still birth & 1 & $1.3 \%$ \\
\hline
\end{tabular}

In present study, the incidence of maternal complications in the case of subclinical hypothyroidism was preeclampsia $(11.1 \%)$, preterm delivery $(8 \%)$, abortions $(5.5 \%)$ and abruptio placentae $(2.7 \%)$. In the present study, the incidence of fetal complication in the case of subclinical hypothyroidism was IUGR (6.9\%), low birth weight $(5.5 \%)$, stillbirth $(1.3 \%)$.

Table 4: Maternal and fetal complication among patient of overt hypothyroidism.

\begin{tabular}{|lll|}
\hline Complication & $\begin{array}{l}\text { No. of cases in } \\
\mathbf{1 0 0 0} \text { patients }\end{array}$ & Percentage \\
\hline Preeclampsia & 6 & $17.6 \%$ \\
\hline Preterm delivery & 5 & $14.7 \%$ \\
\hline Abortion & 2 & $5.8 \%$ \\
\hline Abruptio placentae & 1 & $2.9 \%$ \\
\hline IUGR & 4 & $11.7 \%$ \\
\hline Low birth weight & 3 & $8.8 \%$ \\
\hline Still birth & 1 & $2.9 \%$ \\
\hline
\end{tabular}

In the present study, the incidence of maternal complication in case of overt hypothyroidism was preeclampsia (17.6), percent preterm delivery (14.7\%), abortion $(5.8 \%)$, abruptio placenta $(2.9 \%)$. The incidence of fetal complications in case of overt hypothyroidism was IUGR (11.7\%), low-birth-weight (8.8\%), stillbirth $(2.9 \%)$.
Table 5: Maternal and fetal complication among patient of subclinical hyperthyroidism.

\begin{tabular}{|ll|l|}
\hline $\begin{array}{l}\text { Complication of } \\
\text { subclinical } \\
\text { hyperthyroidism }\end{array}$ & $\begin{array}{l}\text { No. of cases in } \\
\mathbf{1 0 0 0} \text { Patients }\end{array}$ & Percentage \\
\hline Preeclampsia & 3 & $21.4 \%$ \\
\hline Preterm delivery & 1 & $7.1 \%$ \\
\hline Abortion & 1 & $7.1 \%$ \\
\hline IUGR & 3 & $21.4 \%$ \\
\hline Still birth & 1 & $7.1 \%$ \\
\hline
\end{tabular}

In the present study, the incidence of maternal complication in case of subclinical hyperthyroidism was preeclampsia $(21.4 \%)$, preterm delivery $(7.1 \%)$, abortion $(7.1 \%)$ and incidence of fetal complication was IUGR $(21.4 \%)$, stillbirth $(7.1 \%)$.

Table 6: Maternal and fetal complication among patient of overt hyperthyroidism.

\begin{tabular}{|lll|}
$\begin{array}{l}\text { Complication of overt } \\
\text { hyperthyroidism }\end{array}$ & $\begin{array}{l}\text { No. of cases in } \\
\mathbf{1 0 0 0} \text { patients }\end{array}$ & Percentage \\
\hline Abortion & 5 & $27.7 \%$ \\
\hline IUGR & 4 & $11.7 \%$ \\
\hline Still birth & 1 & $7.1 \%$ \\
\hline
\end{tabular}

The incidence of maternal complication in cases of overt hyperthyroidism was abortion $(27.7 \%)$ and incidence of fetal complication was IUGR $(11.7 \%)$.

\section{DISCUSSION}

This study conducted in RKDF Medical College and Research Centre, Bhopal, Madhya Pradesh, India. The aim of study was to evaluate the prevalence of thyroid disorder in pregnancy and pregnancy outcome.

All pregnant women enrolled for study screened using serum TSH level and who had elevated TSH level, ft3 and $\mathrm{ft} 4$ was done.

Table 7: Comparison of incidence of complication in pregnant women having subclinical hypothyroidism.

\begin{tabular}{|llllllll|}
\hline & Preeclampsia & $\begin{array}{l}\text { Preterm } \\
\text { delivery }\end{array}$ & Abortion & $\begin{array}{l}\text { Abruptio } \\
\text { placenta }\end{array}$ & IUGR & $\begin{array}{l}\text { Low birth } \\
\text { weight }\end{array}$ & $\begin{array}{c}\text { Still birth } \\
\text { Sahu MT et al }\end{array}$ \\
\hline Taghavi et al & $9.8 \%$ & $10.3 \%$ & - & - & $2.4 \%$ & - & $2.5 \%$ \\
\hline Lang et al $^{12}$ & $2.7 \%$ & $2.7 \%$ & - & - & - & - & - \\
\hline Ajmani et al $^{6}$ & $15 \%$ & $9 \%$ & - & - & - & $9 \%$ & - \\
\hline In present study & $11.1 \%$ & $5.8 \%$ & $2.39 \%$ & - & $4.9 \%$ & $12.11 \%$ & $1.7 \%$ \\
\hline
\end{tabular}

\section{Observation in this study}

- Prevalence of thyroid disorder in pregnancy $12.4 \%$
- Prevalence of subclinical hypothyroidism $7.2 \%$

- Prevalence of overt hypothyroidism 3.4\%

- Prevalence of subclinical hyperthyroidism $1.4 \%$

- Prevalence of overt hyperthyroidism $0.4 \%$. 
Prevalence of thyroid disorder in pregnancy, in this study is $12.4 \%$ which is comparable to study conducted by Ajmani et al, $13.25 \%$, Taghavi et al, $14.6 \%$, Wang et al, $10.2 \% .^{6-8}$

The study conducted by Tanuja et al, prevalence of thyroid disorder was less $5 \%$ and study conducted by Rajput et al, prevalence of thyroid disorder was higher $26.5 \%$ and not compatible with this study. ${ }^{9,10}$

In pregnant women having subclinical hypothyroidism, Incidence of pre-eclampsia $11.1 \%$, preterm delivery $8 \%$, abortion $5.5 \%$, abruptio placenta $2.1 \%$, IUGR $6.9 \%$, low birth weight $5.5 \%$, and still birth $1.3 \%$ in this study (Table 7).

Study conducted by Sahu MT et al, incidence of preeclampsia $9.8 \%$, preterm delivery $10.3 \%$, IUGR $2.4 \%$, stillbirth $2.5 \% .^{11}$ In this study there was no incidence of abortion and abruptio placentae but in the present study it is $5.5 \%$ and $2.7 \%$ respectively, which is significant.

Study by Taghavi et al, incidence of complication in pregnant women with subclinical hypothyroidism preeclampsia $2.7 \%$ and preterm delivery $2.7 \% .^{7}$ There was no in incidence of abortion in Taghavi et al study. ${ }^{7}$ Study conducted by Lang et al, incidence of preeclampsia $15 \%$, preterm delivery $9 \%$ low birth weight $9 \%$, which is slightly more than present study. ${ }^{12}$

Study conducted by Ajmani et al, incidence of preeclampsia $22.3 \%$, preterm delivery $5.8 \%$, abortion $2.3 \%$, IUGR $4.9 \%$, low birth weight $12.1 \%$ and still birth $1.7 \% .^{6}$ Incidence of complication preeclampsia $(22 \%)$ and low birth weight $(12.11 \%)$ was more than the present study and incidence of preterm delivery (5.8\%) IUGR (4.9\%), abortion $(2.3 \%)$ was slightly less than present study.

Table 8: Comparison of incidence of complication in pregnant women having overt hypothyroidism.

\begin{tabular}{|ll|llllll|}
\hline & Preeclampsia & $\begin{array}{l}\text { Preterm } \\
\text { delivery }\end{array}$ & Abortion & $\begin{array}{l}\text { Abruptio } \\
\text { placenta }\end{array}$ & IUGR & $\begin{array}{l}\text { Low birth } \\
\text { weight }\end{array}$ & $\begin{array}{l}\text { Still birth } \\
\text { Sahu MT et al }\end{array}$ \\
\hline Lang et al & $20.7 \%$ & $4.7 \%$ & - & - & $13.8 \%$ & - & $2.9 \%$ \\
\hline Ajmani et al & $22 \%$ & - & - & - & - & $22 \%$ & $4 \%$ \\
\hline In present study & $16.6 \%$ & $33.3 \%$ & $16.6 \%$ & $16.6 \%$ & $25 \%$ & $50 \%$ & $16 \%$ \\
\hline
\end{tabular}

Table 9: Comparison of incidence of complication in pregnant women having subclinical hyperthyroidism.

\begin{tabular}{|ll|llllll|} 
& Preeclampsia & $\begin{array}{l}\text { Preterm } \\
\text { delivery }\end{array}$ & Abortion & $\begin{array}{l}\text { Abruptio } \\
\text { placenta }\end{array}$ & IUGR & $\begin{array}{l}\text { Low birth } \\
\text { weight }\end{array}$ & \multicolumn{1}{c|}{$\begin{array}{l}\text { Still birth } \\
\text { Taghavi et } \mathrm{al}^{7}\end{array}$} \\
\hline In present study & $4.7 \%$ & $4.7 \%$ & - & - & - & - & - \\
\hline
\end{tabular}

In present study incidence of complication in pregnant women with overt hypothyroidism preeclampsia $17.6 \%$, preterm delivery $14.7 \%$, abortion $5.8 \%$, abruption $2.9 \%$, IUGR $11.7 \%$, low birth weight $8.8 \%$, still birth $2.9 \%$.

Study conducted by Ajmani et al, incidence of preeclampsia is $16.6 \%$, preterm delivery $13.3 \%$, abortion $16.6 \%$, abruption $16.6 \%$, IUGR $25 \%$, low-birth-weight $50 \%$, still birth $16.6 \% .^{6}$ Study conducted by Sahu MT et al, Incidence of preeclampsia $27 \%$, preterm delivery $4.7 \%$, IUGR $13.8 \%$, stillbirth $2.9 \% .^{11}$

Study conducted by Lang et al, incidence of complication in pregnant women with overt hypothyroidism preeclampsia $22 \%$, low birth weight $22 \%$, still birth $4 \%{ }^{12}$

In present study Incidence of abortion was $5.8 \%$, which is significant and not found in any other study except study conducted by Ajmani et al, which showed incidence of abortion as $16.6 \% .^{6}$

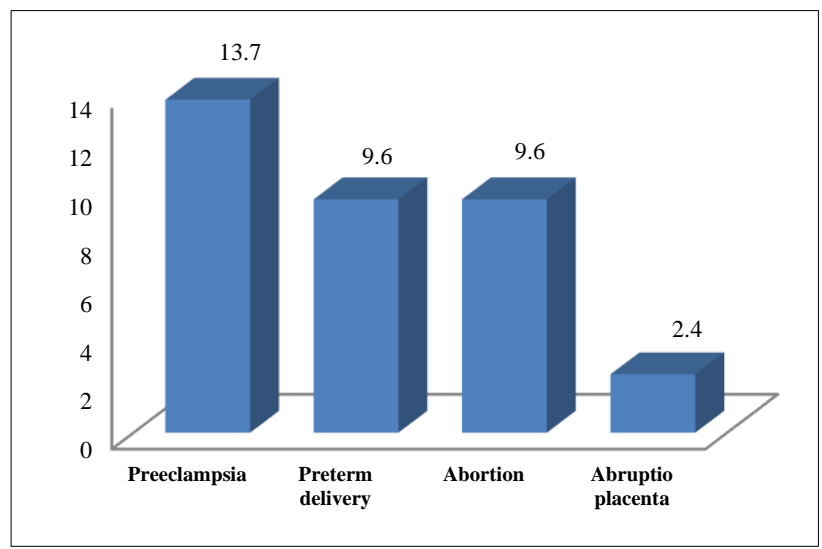

Figure 1: Incidence of maternal complication in thyroid disorder. 


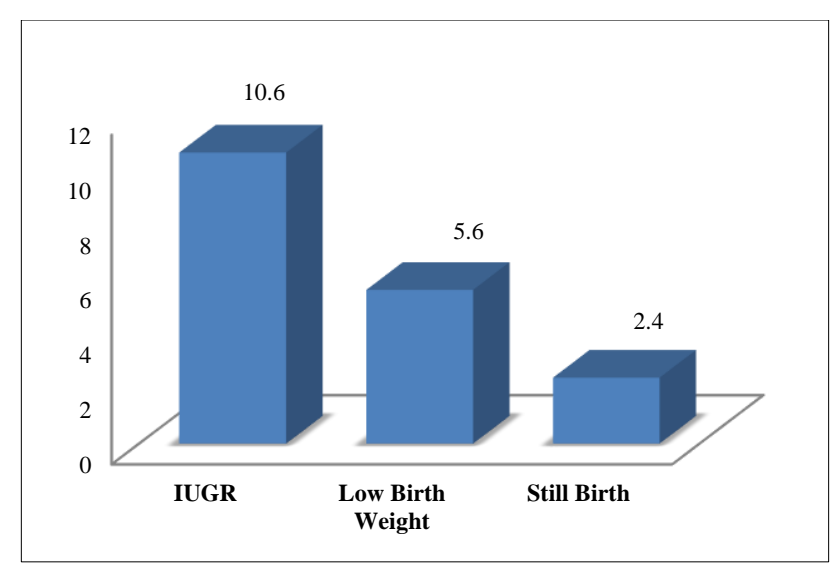

Figure 2: Incidence of foetal complication in thyroid disorder.

Incidence of complication in pregnant women in present study with subclinical hyperthyroidism, preeclampsia $21.4 \%$, preterm delivery $7.1 \%$, abruption $7.1 \%$. IUGR $16.6 \%$ and Stillbirth $5.5 \%$ (Table 9). Study conducted by Taghavi et al, incidence of preeclampsia $4.7 \%$ preterm delivery $4.7 \% .^{7}$ Incidence of maternal complication in 124 pregnant women with thyroid disorder preeclampsia $(13.7 \%)$, abortion $(9.6 \%)$, preterm delivery (9.6\%), abruptio placenta (2.4\%) (Figure 1).

The incidence of fetal complication in 124 pregnant women with thyroid disorder was IUGR (10.6\%) stillbirth $(2.4 \%)$, low birth weight $(5.6 \%)$ as per Figure 2.

\section{CONCLUSION}

This study showed a high prevalence of thyroid disorder in pregnant women. Thyroid disorders associated with several of obstetric and fetal complication and timely detection and optimal treatment of thyroid disorder, reduce the risk of the complication and because of high prevalence of thyroid disorder in pregnancy in India, Universal screening of pregnant woman is required.

\section{ACKNOWLEDGMENTS}

Authors would like to thank the Dean, RKDF Medical College and Research Centre, Bhopal, Madhya Pradesh, India.

Funding: No funding sources

Conflict of interest: None declared

Ethical approval: The study was approved by the Institutional Ethics Committee

\section{REFERENCES}

1. Vaidya B. Management of hypothyroidism in pregnancy: we must do better. Clin Endocrinol. 2013;78:342-3.

2. Milanesi A, Brent GA. Management of hypothyroidism in pregnancy. Curr opin Endocr, Diab andobes. 2011;18:304-9.

3. Ian Donald's, Practical obstetric problems, $6^{\text {th }}$ edition, Delhi, India: Renu Misra; 2012:177.

4. Sutandar M, Garcia-Bournissen F, Koren G. Hypothyroidism in pregnancy. J Obstet Gynaecol Can. 2007;29(4):354-6.

5. Smallridge RC, Ladenson PW. Hypothyroidism in pregnancy: consequences to neonatal health. J Clin Endor Metab. 2001;86(6):2349-53.

6. Ajmani SN, Aggarwal D, Bhatia P, Sharma M, Sarabhai V, Paul M. Prevalence of overt and subclinical thyroid dysfunction among pregnant women and its effect on maternal and fetal outcome. The J Obstet Gynaecol India. 2014;64(2):105-10.

7. Taghavi M, Sughafi N, Shirin S. Outcome of thyroid dysfunction in pregnancy in Mashhad, Iran. Inl J Endocrinol Metab. 2009;2:82-5.

8. Wang W, Teng W, Shan Z, Wang S, Li J, Zhu L, et al. The prevalence of thyroid disorder during early pregnancy in China: the benefits of universal screening in the first trimester of pregnancy. Eur $\mathbf{J}$ Endocrinol. 2011;164:263-8.

9. Thanuja PM, Rajgopal K. Thyroid dysfunction in pregnancy and its maternal. J Dent Med Sci. 2014;13(1):11-5.

10. Goel V, Nanda S, Rajput M, Seth S. Prevalence of thyroid dysfunction among women during the first trimester of pregnancy at a tertiary care hospital in Haryana. Inl J Endocrinol Metab. 2015;19(3):416-9.

11. Sahu MT, Das V, Mittal S, Agarwal A, Sahu M. Overt and subclinical thyroid dysfunction among Indian pregnant women and its effect on maternal and fetal outcome. Arch Gynaecol Obstet. 2010;281(2):215-20.

12. Leung AS, Millar LK, Kooning PP, Montorom, Mestman J. Perinatal outcome in hypothyroid pregnancies. Obstetric Gynaecol. 1993;81(3):349-53.

Cite this article as: Jain MG, Jain NK, Mazumdar M. A prospective clinical trial to evaluate the prevalence of thyroid disorder among pregnant women and obstetrical and fetal outcome in a tertiary health centre located in central India. Int J Reprod Contracept Obstet Gynecol 2020;9:3393-7. 